\title{
Polymorphisms in 16S rRNA genes of Flavobacterium psychrophilum correlate with elastin hydrolysis and tetracycline resistance
}

\author{
Marilyn Soule ${ }^{1}$, Stacey LaFrentz ${ }^{1}$, Kenneth Cain $^{2,3}{ }^{\text {, Scott LaPatra }}{ }^{4}$, Douglas R. Call ${ }^{1,3, *}$ \\ ${ }^{1}$ Department of Veterinary Microbiology and Pathology, Washington State University, Pullman, Washington 99164-7040, USA \\ ${ }^{2}$ Department of Fish and Wildlife Resources, University of Idaho, Moscow, Idaho 83844-1136, USA \\ ${ }^{3}$ WSU and UI Center for Reproductive Biology, Pullman, Washington 99164-4231, USA \\ ${ }^{4}$ Research Division, Clear Springs Foods, PO Box 712, Buhl, Idaho 83316, USA
}

\begin{abstract}
Flavobacterium psychrophilum is the etiological agent of bacterial coldwater disease, which causes significant problems to aquaculture worldwide. A recent study (Soule M, Cain K, LaFrentz S, Call DR [2005] Infect Immun 73:3799-3802) identified two 16S rRNA gene sequence variants (6 base differences) within the variable stem-loop region 3 for $F$. psychrophilum strains ATCC 49418 and CSF 259-93. That study also hypothesized that F. psychrophilum is composed of at least 2 distinct genetic lineages (I and II) described by a microarray-based comparative genomics study. In the present study, we augmented an existing 16S rDNA microarray to detect both 16S rRNA sequence variants from F. psychrophilum. Subsequent microarray experiments showed that CSF 259-93 hybridized as expected, but ATCC 49418 was positive for both sequence variants. We then developed a PCR-restriction fragment length polymorphism (RFLP) assay (MnlI and MaeIII) to distinguish between the 2 sequences. Gel isolation of PCR-RFLP products, cloning, and sequencing confirmed that ATCC 49418 harbors both 16S rRNA sequences. Microarray experiments showed that 11 of 14 strains from genetic Lineage I harbor both the CSF 259-93 and ATCC 49418 16S rRNA sequence variants, whereas all 15 Lineage II strains were only positive for the CSF 259-93 sequence ( $<<$ 0.0001). Elastin hydrolysis and tetracycline resistance were most closely associated with the latter strains $(\mathrm{p}<0.0001$ and $\mathrm{p}=0.024$, respectively). These data support the hypothesis that $F$. psychrophilum is composed of at least 2 distinct genetic lineages that are closely associated with host origin.
\end{abstract}

KEY WORDS: 16S rRNA · Flavobacterium psychrophilum • Bacterial coldwater disease · Elastin hydrolysis · Microarray hybridization · Tetracycline resistance

\section{INTRODUCTION}

Flavobacterium psychrophilum is the etiological agent of bacterial coldwater disease (BCWD), which is also referred to as rainbow trout fry syndrome (RTFS) in Europe (Lorenzen et al. 1997). BCWD is primarily a disease of salmonids although other commercially important fish species can be affected (Iguchi et al. 2003, Nematollahi et al. 2003). BCWD - or RTFS — can have severe impacts on aquaculture and there have been reports of this diseases worldwide (Bernardet et al. 1988, Wakabayashi et al. 1991, Toranzo \& Barja 1993, Wik- lund et al. 1994, Bustos et al. 1995, Ekman et al. 1999, Dalsgaard \& Madsen 2000). At present there is no commercial vaccine available and the primary prevention strategy is careful population management (e.g. reduced stocking densities and feed rate adjustment). Stress is a significant contributor to disease outbreaks (Holt et al. 1989, Groff \& LaPatra 2000, Madetoja et al. 2000, Iguchi et al. 2003). Oxytetracycline is the only treatment approved in the United States, but there are reports of increased antimicrobial resistance among F. psychrophilum isolates (Rangdale et al. 1997, Bruun et al. 2000, Schmidt et al. 2000, Bruun et al. 2003). 
In general, Flavobacterium psychrophilum strains are biochemically homogeneous, with the exception of some variation in the presence or absence of caseinases, gelatinases, and elastases (Bertolini et al. 1994, Lorenzen et al. 1997, Madetoja et al. 2001, 2002). Not all strains of F. psychrophilum are capable of causing the same degree of disease (Holt 1987, Madetoja et al. 2002, LaFrentz et al. 2003) and they can be antigenically diverse (Evensen \& Lorenzen 1996, Madsen \& Dalsgaard 2000, Crump et al. 2001, Madetoja et al. 2002). Immunization with killed cells of one strain does not necessarily convey protective immunity from infection by other strains (Holt et al. 1989, Obach \& Laurencin 1991, LaFrentz et al. 2004).

Genetic variation has been assessed between strains using ribotyping, plasmid profiles, randomly amplified polymorphic DNA (RAPD), and PCR-RFLP of specific gene fragments (Chakroun et al. 1997, Chakroun et al. 1998, Madsen \& Dalsgaard 2000, Madetoja et al. 2001, 2002, Izumi et al. 2003). Studies of outbreak strains from Danish trout farms suggest dominance by a single ribotype (Madsen \& Dalsgaard 2000, Madetoja et al. 2002), but other studies show greater genetic variation across geographic scales (Chakroun et al. 1997, 1998, Madetoja et al. 2000). Izumi et al. (2003) and Chakroun et al. (1998) published evidence for host-species associations between different strains of Flavobacterium psychrophilum. In a recent study, Soule et al. (2005) used comparative genomic hybridizations with DNA microarrays and demonstrated that 34 geographically diverse strains of $F$. psychrophilum could be classified into 2 distinct genetic lineages that correlate well with either trout or salmon origin. The study reported herein provides further genetic and phenotypic evidence that supports the hypothesis that F. psychrophilum strains can be classified into at least 2 distinct genetic lineages.

\section{MATERIALS AND METHODS}

Bacterial strains and media. All Flavobacterium psychrophilum stains used in this study are described in Table 1 . Strains were recovered from $-80^{\circ} \mathrm{C}$ glycerol stocks by streak isolation on agar plates (tryptone yeast extract salts medium, 1× TYES [0.4\% tryptone, $0.05 \%$ yeast extract, $0.0074 \%$ anhydrous calcium chloride, $0.05 \%$ magnesium sulphate heptahydrate, $\mathrm{pH} 7.2$ ] or $2 \times$ TYES [0.8\% tryptone, $0.1 \%$ yeast extract, $0.0074 \%$ anhydrous calcium chloride, $0.05 \%$ magnesium sulphate heptahydrate, $\mathrm{pH} 7.2 \mathrm{l}$ ) and incubation at $17^{\circ} \mathrm{C}$. Individual colonies were picked and grown at $17^{\circ} \mathrm{C}$ in $1 \times$ TYES broth for processing. Species identification was verified by hybridization to a $16 \mathrm{~S}$ rDNA microarray (Warsen et al. 2004) and 8 of the strains were also confirmed by a nested PCR assay (Baliarda et al. 2002) as part of a separate study (K. Cain \& D. Call unpubl. data).

Microarray fabrication. A microarray composed of rDNA oligonucleotides from 15 fish pathogens (Warsen et al. 2004) was modified by the addition of a new oligonucleotide probe specific to a $16 \mathrm{~S}$ rRNA gene polymorphism identified in Flavobacterium psychrophilum strain CSF 259-93 (Fig. 1; GAAACACTCGGTCGTGACCGAGCT). Briefly, oligonucleotides (21to 32-mer sequences) were synthesized (Invitrogen) and resuspended in print buffer. Quadruplicate spots of each oligonucleotide were printed in 8 wells of 10well Teflon-masked slides (Erie Scientific) using a Microgrid II Arrayer (BioRobotics [now Genomic Solutions]). Each array contained quadruplicate spots of a biotinylated oligonucleotide as a control for detection chemistry.

Sample hybridization. Genomic DNA (gDNA) was extracted from Flavobacterium psychrophilum strains using the DNeasy tissue kit (Qiagen). 16S rRNA gene fragments were amplified in a $50 \mu \mathrm{lCR}$ reaction con-

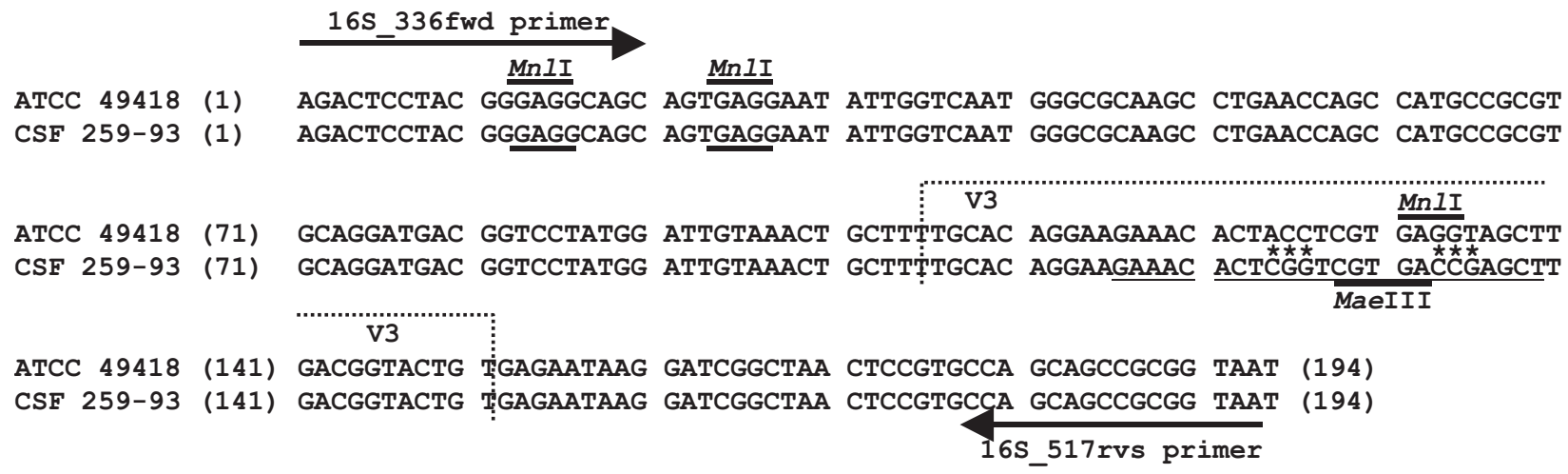

Fig. 1. DNA sequence alignment of a $194 \mathrm{bp}$ region of the 16S rRNA genes from Flavobacterium psychrophilum strains ATCC 49418 and CSF 259-93. Polymorphic nucleotides are highlighted with asterisks $(* * *)$, and 2 primer locations are indicated by arrows. Solid black lines represent restriction enzyme sites. Underlined sequence represents the DNA sequence used for the microarray probe. Variable Region 3 (Baker et al. 2003) is indicated with a dotted line 
Table 1. Flavobacterium psychrophilum strains used in this study. Putative genetic lineage defined by Soule et al. (2005). Source of isolates: ATCC (American Type Culture Collection, Manassas, VA); CFG (California Department of Fish and Game Sacramento, CA); I. Dalsgaard (Fish Disease Laboratory, Danish Institute for Fisheries Research, Frederiksberg, Denmark); J. Bertolini (Northwest Indian Fisheries Commission, Olympia, WA); J. Winton (USGS Western Fisheries Research Center, Seattle, WA); P. Taylor (Abernathy Fish Technology Center, Longview, WA); S. LaPatra (Clear Springs Foods, Buhl, ID); UWR (Utah Division of Wildlife Resources, Salt Lake City, UT); WADDL (Washington Animal Disease Diagnostic Laboratory, WSU, Pullman, WA). A = 16S rRNA PCR product hybridized to probe from ATCC 49418 sequence; C = 16S rRNA PCR product hybridized to probe from CSF 259-93 sequence. A\&C = hybridization was positive for both probes. Elastin hydrolysis given as positive (+) or negative (-)

\begin{tabular}{|c|c|c|c|c|}
\hline Strain name (Lineage) & Host species & Isolate source & 16S rRNA & Elastin hydrolysis \\
\hline ATCC $49418^{\mathrm{a}}(\mathrm{I})$ & Coho salmon Oncorhynchus kisutch & ATCC (type strain) & $\mathrm{A} \& \mathrm{C}$ & - \\
\hline Quilcene C5 (I) & Coho salmon & P. Taylor & $A \& C$ & - \\
\hline W98-317-16K (I) & Coho salmon & P. Taylor & $\mathrm{C}$ & - \\
\hline EC98-305-5402K (I) & Coho salmon & P. Taylor & $\mathrm{C}$ & - \\
\hline Quilcene C7 (I) & Coho salmon & P. Taylor & $A \& C$ & - \\
\hline AFTC P-3 (I) & Chinook salmon O. tshawytscha & P. Taylor & $A \& C$ & + \\
\hline AFTC C2 (I) & Chinook salmon & P. Taylor & $A \& C$ & - \\
\hline 446-96 (I) & Atlantic salmon Salmo salar & J. Winton & $A \& C$ & + \\
\hline $454-96(\mathrm{I})$ & Rainbow trout $O$. mykiss & J. Winton & $A \& C$ & - \\
\hline $99-10 \mathrm{~A}(\mathrm{I})$ & Rainbow trout & I. Dalsgaard & C & - \\
\hline SH3-81 (I) & Coho salmon & J. Bertolini & $A \& C$ & - \\
\hline 03-398-1 (I) & Coho salmon & J. Bertolini & $A \& C$ & + \\
\hline 03-449-5 (I) & Coho salmon & J. Bertolini & $A \& C$ & - \\
\hline $03-169(\mathrm{I})$ & Coho salmon & J. Bertolini & $\mathrm{A} \& \mathrm{C}$ & - \\
\hline CSF 259-93 (II) & Rainbow trout & S. LaPatra & $\mathrm{C}$ & + \\
\hline EL-SH-10K (II) & Steelhead O. mykiss & P. Taylor & $\mathrm{C}$ & + \\
\hline F12 617 (II) & Rainbow trout & WADDL & $\mathrm{C}$ & + \\
\hline F12 K1 17 (II) & Rainbow trout & WADDL & $\mathrm{C}$ & + \\
\hline C95-74-1 (II) & Sturgeon Acipenser transmontanus & $\mathrm{CFG}$ & $\mathrm{C}$ & + \\
\hline 464-96 Fsp RBT (II) & Rainbow trout & J. Winton & $\mathrm{C}$ & + \\
\hline 463-96 Fsp RBT5 (II) & Rainbow trout & J. Winton & $\mathrm{C}$ & + \\
\hline 622-97 Fp 705-97 (II) & Atlantic salmon & J. Winton & $\mathrm{C}$ & + \\
\hline 621-97 Fp 259 (II) & Atlantic salmon & J. Winton & $\mathrm{C}$ & + \\
\hline 623-97 Fp 712-97 (II) & Rainbow trout & J. Winton & $\mathrm{C}$ & + \\
\hline 950106-1/1 (II) & Rainbow trout & I. Dalsgaard & $\mathrm{C}$ & + \\
\hline 900406-1/3 (II) & Rainbow trout & I. Dalsgaard & $\mathrm{C}$ & + \\
\hline 99/1A (II) & Rainbow trout & I. Dalsgaard & $\mathrm{C}$ & + \\
\hline 03-009 (II) & Rainbow trout & UWR & $\mathrm{C}$ & + \\
\hline $2004-1220$ (II) & Rainbow trout & WADDL & $\mathrm{C}$ & + \\
\hline
\end{tabular}

taining $50 \mathrm{ng}$ gDNA as template and $0.4 \mu \mathrm{M}$ each of primers 16S_336fwd (AGACTCCTACGGGAGGCAGC, Warsen et al. 2004) and 16S_517rvs (ATTACCGCGGCTGCTGG, Muyzer et al. 1993). The PCR program included an initial denaturing step at $95^{\circ} \mathrm{C}$ for $5 \mathrm{~min}$, followed by 28 cycles of $95^{\circ} \mathrm{C}$ for $30 \mathrm{~s}, 62^{\circ} \mathrm{C}$ for $1 \mathrm{~min}$, and $72^{\circ} \mathrm{C}$ for $1 \mathrm{~min}$, with a final extension step of $72^{\circ} \mathrm{C}$ for $10 \mathrm{~min}$. PCR products were purified by using ethanol precipitation, resuspended in $\mathrm{H}_{2} \mathrm{O}$, and nicktranslated for $1 \mathrm{~h}$ in the presence of biotin-dATP (BioNick Labeling System; Invitrogen). Labeled PCR products were purified by using ethanol precipitation and resuspended in $90 \mu \mathrm{l}$ hybridization buffer $(4 \times$ saline sodium citrate, SSC [ $60 \mathrm{mM} \mathrm{NaCl}, 0.6 \mathrm{mM} \mathrm{Na}$-citrate, pH 7.0] and 5× Denhardt's solution [0.1\% Ficoll, $0.1 \%$ polyvinylpyrrolidone, $0.1 \%$ bovine serum albumin]), then further diluted between 1:2 and 1:10 in hybridization buffer depending on initial hybridization results.
Slide wells were preblocked at $23^{\circ} \mathrm{C}$ for $30 \mathrm{~min}$ with TNB buffer (100 mM Tris-HCl [pH 7.5], $150 \mathrm{mM} \mathrm{NaCl}$, $0.5 \%$ blocking reagent, Tyramide Signal Amplification $^{\mathrm{TM}}$ [TSA] Biotin System; Perkin-Elmer). Biotinylated target $(45 \mu \mathrm{l}$ per well) was heat-denatured, applied to duplicate wells on the slide and incubated overnight in a humidified chamber at $55^{\circ} \mathrm{C}$. The remaining detection steps were carried out as previously described (Warsen et al. 2004) with $45 \mu \mathrm{l}$ of the appropriate reagent applied to each well of the slide at each step. Images were captured with an arrayWoRx ${ }^{\text {етм }}$ scanner (Applied Precision). Images were evaluated visually to determine presence or absence of hybridized target sequences.

PCR-restriction fragment length polymorphism (PCR-RFLP). We used PCR-RFLP to identify the presence of predicted sequence variants for the 16S rRNA gene. A $194 \mathrm{bp}$ fragment of 16S rDNA was PCR-ampli- 
fied as described using 16S_336fwd and 16S_517rvs primers and gDNA as template. A $2.5 \mu \mathrm{l}$ aliquot of the PCR product was examined by agarose electrophoresis and the remaining PCR product was ethanol precipitated and resuspended in $27.5 \mu \mathrm{l}$ nanopure water. This PCR product $(25 \mu \mathrm{l})$ was then digested with $2 \mathrm{U}$ MaeIII (at $55^{\circ} \mathrm{C}$ ) or $2 \mathrm{U}$ MnlI $\left(\right.$ at $37^{\circ} \mathrm{C}$ ) for $1 \mathrm{~h}$. The digested products were ethanol precipitated, resuspended in nanopure water, and fragments separated on either $1.5 \%$ agarose or $3.0 \%$ MetaPhor agarose (FMC BioProducts) gels. Bands were visualized with ethidium bromide and UV light.

Sequencing gel-isolated PCR products. Restriction fragments (MnlI) of the $194 \mathrm{bp} 16 \mathrm{~S}$ rRNA PCR product were identified using gel electrophoresis with $3 \%$ MetaPhor agarose (FMC BioProducts). Fragments of interest were extracted from the gel with a Montage spin column (Millipore), ligated to pCR2.1 (Invitrogen), and used to transform Escherichia coli TOP10 (Invitrogen). Bacterial lysates were prepared for 5 transformants. Lysate was then used as template in a PCR reaction to amplify the $194 \mathrm{bp} 16 \mathrm{~S}$ rRNA fragment. The resulting PCR products were ethanol precipitated, digested with MaeIII and examined using gel electrophoresis (3\% MetaPhor agarose). Plasmids were extracted from all 5 of the colonies used to prepare the bacterial lysates: 1 from a plasmid containing an insert that was not digested by MaeIII and 4 that were digested by MaeIII. The inserts of all plasmids were sequenced (Amplicon Express).

Gelatin hydrolysis. Hydrolysis of Type A and Type B gelatin (Sigma Chemical) was tested by stabbing isolates into test-tubes containing $0.5 \mathrm{ml} 2 \times$ TYES supplemented with $4 \%$ gelatin (Type A or Type B, separately). Tubes were incubated at $17^{\circ} \mathrm{C}$ for $10 \mathrm{~d}$. Liquefaction of at least a portion of the medium indicated a positive result for gelatin hydrolysis.

Elastin hydrolysis. Agar plates of $2 \times$ TYES supplemented with 0.5 or $0.05 \%$ elastin from bovine neck ligament (Sigma) were inoculated with $5 \mu \mathrm{l}$ of log-phase culture adjusted to an optical density at $600 \mathrm{~nm}\left(\mathrm{OD}_{600}\right)$ of 0.8 . Plates were incubated at $17^{\circ} \mathrm{C}$ for $10 \mathrm{~d}$. Clearance of the cloudy media around the colony was recorded as a positive result for elastin hydrolysis.

Tetracycline resistance test. Susceptibility of all isolates to tetracycline was evaluated using the Kirby-Bauer method (Bauer et al. 1966). BD BBL Sensi-Disc Antimicrobial Susceptibility Test Discs (Becton Dickinson) containing $5 \mu \mathrm{g}$ tetracycline per disc were used according to the manufacturer's protocol, except that log-phase broth cultures were adjusted to an $\mathrm{OD}_{600}$ of 0.8 , dilute modified Meuller-Hinton agar (Hawke \& Thune 1992) was used, and isolates were incubated at $17^{\circ} \mathrm{C}$ for $3 \mathrm{~d}$ before recording zone sizes. NCSS 2001 software (NCSS Statistical Software) was used for all statistical tests.

\section{RESULTS}

We used a fish pathogen microarray from Warsen et al. (2004) to confirm the identity of Flavobacterium psychrophilum isolates that were obtained from various diagnostic laboratories. During initial testing of this system, we demonstrated that the type strain, ATCC 49418, hybridizes to the array as expected, but that the CSF 259-93 strain does not. We subsequently sequenced most of the 16S rRNA gene from each of these isolates and discovered 6 base differences for these 2 strains, all of which were detected within the region targeted by the fish pathogen microarray (Fig. 1) (Soule et al. 2005).

In the present study, we augmented the 16S rRNA microarray with a probe that detects the CSF 259-93 sequence and we confirmed the expected hybridization results for CSF 259-93 (Fig. 2). Interestingly, however, when ATCC 49418 was hybridized to the new microarray we detected positive signal for the ATCC 49418 specific probe and the CSF 259-93 specific probe (Fig. 2). Assuming that Flavobacterium psychrophilum has more than one 16S rRNA open reading frame within its genome, these results suggest that both probe sequences are present in the ATCC 49418 genome, whereas the ATCC 49418 sequence is not present in the CSF 259-93 genome.

\section{S rRNA sequences in strain ATCC 49418}

Based on the 16S rRNA sequences from CSF 259-93 and ATCC 49418, it was possible to design a PCRRFLP test that differentiates between these 2 sequences (Fig. 1). A $194 \mathrm{bp}$ PCR product was generated from the 16S rRNA gene for both ATCC 49418 and CSF 259-93 and these products were subsequently digested with restriction enzymes (Fig. 3). Digestion of the CSF 259-93 product with MnlI produced no cuts, which was predicted, whereas digestion with MaeIII produced 2 fragments of the predicted size (64 and $128 \mathrm{bp}$ ). Digestion of the ATCC 49418 product with MnlI produced 2 fragments of the predicted size (105 and $62 \mathrm{bp}$ ) although a considerable amount of product was undigested (194 bp) or incompletely digested (ca. $77 \mathrm{bp}$ ). MaeIII digest produced 2 faint bands (64 and $128 \mathrm{bp}$ ) consistent with the presence of a CSF 259-93 sequence in the ATCC 49418 genome.

To confirm the existence of a second 16S rRNA sequence, we again generated the 16S rDNA PCR products from ATCC 49418, digested the products with MnlI, and isolated the undigested 194 bp fragment directly from an agarose gel. DNA from this gel slice was subsequently cloned into a plasmid vector and used to transform an Escherichia coli host. Five trans- 

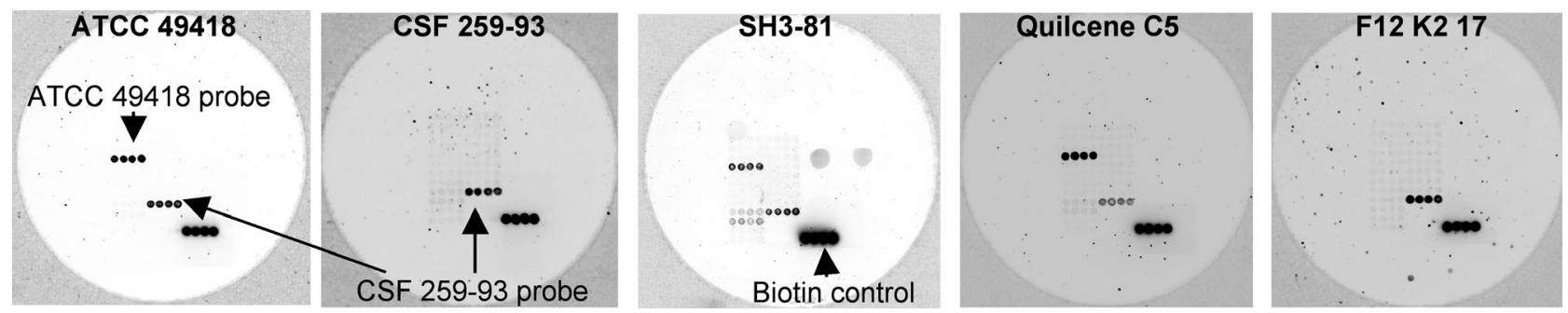

Fig. 2. Flavobacterium psychrophilum. Microarray results of 5 representative strains. Bold type indicates the strain hybridized to the microarray. Locations of quadruplicate sets of relevant probes are indicated by arrows

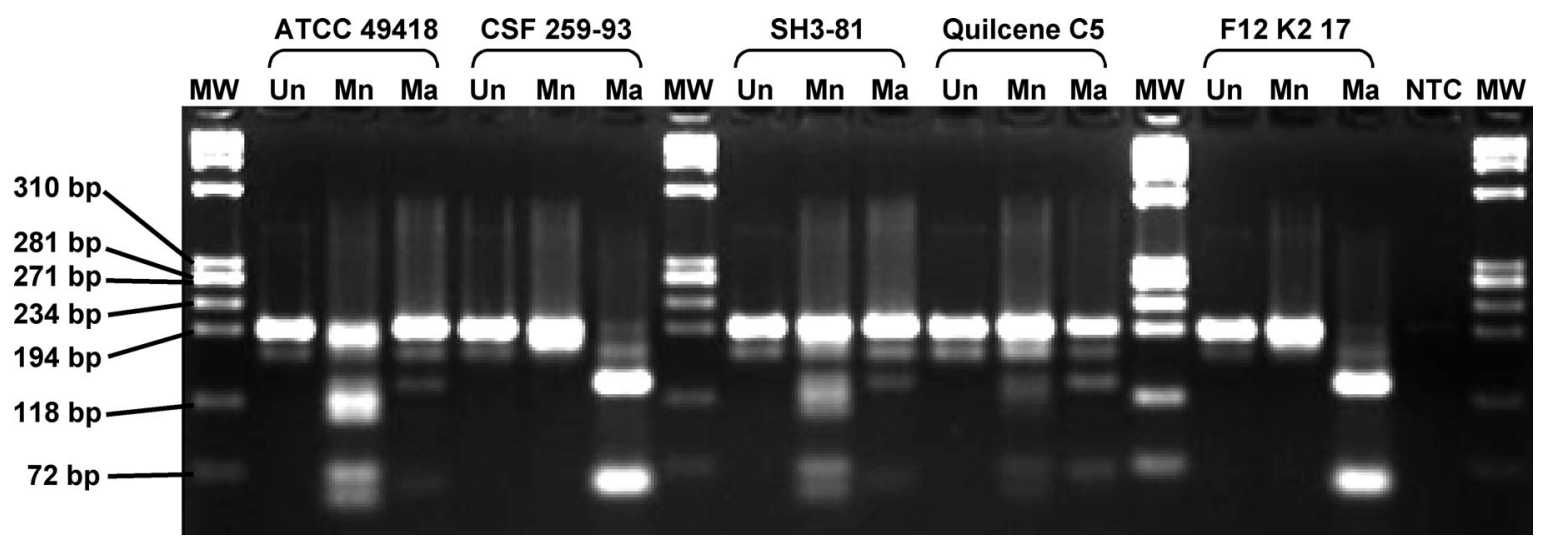

Fig. 3. Flavobacterium psychrophilum. PCR-RFLP results of 5 representative strains. 16S rRNA PCR products were generated and restriction-enzyme digested with no enzyme (Un), with MnlI (Mn), or with MaeIII (Ma). NTC = no template control; MW = molecular weight marker

formants were analyzed by PCR-RFLP and 4 were positive for the presence of the MaeIII restriction site, whereas the other one was not digested with this enzyme. We sequenced both the MaeIII positive and negative cloned inserts and confirmed that the former harbored the CSF 259-93 sequence, while the latter harbored the ATCC 48419 sequence. These results are consistent with the presence of at least 2 distinct $16 \mathrm{~S}$ rRNA sequences in the ATCC 49418 genome.

\section{Distribution of rRNA sequences in Flavobacterium psychrophilum strains}

We determined the distribution of the ATCC 49418 and CSF 259-93 16S rRNA sequences for a panel of isolates that were previously characterized using a custom DNA microarray (Soule et al. 2005). Only 29 of the 34 original isolates were included in the present analysis because of difficulty retrieving viable cells of the remaining 5 isolates. PCR products (194 bp) were generated from the 16S rRNA gene for each isolate and were then hybridized to the fish pathogen microarray. All strains hybridized to either the CSF- probe alone or they hybridized to both the ATCC-probe and the CSFprobe (Fig. 2, Table 1). As a validation test, DNA microarray results were confirmed for 11 strains using our 16S rDNA PCR-RFLP assay as described above. For example, strains SH3-81 and Quilcene C5 both hybridized to the 2 F. psychrophilum probes (Fig. 2) and their PCR-RFLP results were consistent with the presence of both 16S rRNA sequences (Fig. 3). Strain F12 K2 17 hybridized to only the CSF 259-93 probe and PCR-RFLP results were consistent with the presence of the CSF 259-93 sequence, but not the ATCC 49418 sequence (Fig. 3).

The distribution of $16 \mathrm{~S}$ rRNA sequences corresponds well with the putative genetic lineages defined by Soule et al. (2005). Most strains (11 of 14) defined as 'Lineage I' were positive for both the CSF-probe and the ATCC-probe (Table 1). All strains from 'Lineage II' ( $n=15$ ) were positive for the CSF-probe only. This distribution of 16S rRNA sequences amongst the 2 putative lineages was significantly different from random (Fisher's exact test, $\mathrm{p}<0.0001$ ).

\section{Phenotypic analyses of Flavobacterium psychrophilum strains}

F. psychrophilum strains are reportedly heterogeneous with respect to their ability to hydrolyze gelatin 
and elastin, and with respect to their susceptibility to tetracycline. Consequently, we examined these phenotypic traits relative to the distribution of the CSF 25993 and ATCC 49418 16S rRNA gene polymorphisms. Gelatin Type A was hydrolyzed by all strains tested except for CSF 259-93 and 454-96. Strain 454-96 was the only strain unable to hydrolyze Gelatin Type B. Most strains (11 of 14) defined as members of Lineage I were negative for elastin hydrolysis, whereas all 15 strains from Lineage II were positive for elastin hydrolysis (Table 1; Fisher's exact test, $\mathrm{p}<0.0001$ ).

Tetracycline resistance was tested using the KirbyBauer disc diffusion method (Bauer et al. 1966). The zone of inhibition was measured for each strain and a smaller zone of inhibition represents greater resistance to tetracycline. Isolates from Lineage I were more susceptible to tetracycline $(36.4 \pm 5.3 \mathrm{~mm})$ compared with isolates from Lineage II $(27.1 \pm 5.3 \mathrm{~mm}$ ) (ANOVA, $\mathrm{p}=0.024)$.

\section{DISCUSSION}

Soule et al. (2005) used suppression subtractive hybridization and DNA microarrays to examine genetic differences between 2 strains of Flavobacterium psychrophilum. One strain (CSF 259-93) is virulent in a trout challenge model, while the second strain (ATCC 49418) is avirulent in this model (LaFrentz et al. 2002, 2003, 2004). The analysis identified 103 DNA fragments that were unique to one or the other strain. Microarrays were used to examine the distribution of these DNA fragments across 34 strains of $F$. psychrophilum that originated from North America, South America, and Europe. The data from Soule et al. (2005) demonstrated the existence of 2 putative genetic lineages of $F$. psychrophilum and showed that these lineages appear to be closely host-associated (salmon vs. trout). Data from the current study supports this putative intra-specific phylogeny. Distinct $16 \mathrm{~S}$ sequences, select carriage of two 16S sequence polymorphisms, elastin hydrolysis, and tetracycline resistance are all consistent with the existence of 2 distinct genetic lineages.

The suggestion that different strains of Flavobacterium psychrophilum might be associated with specific hosts is not without precedence. Izumi et al. (2003) used PCR-RFLP methods to analyze sequence polymorphisms for the gyrB gene and an anonymous fragment of DNA from F. psychrophilum. They reported a particularly strong association between one genotype and ayu Plecoglossus altivelis from Japan. Chakroun et al. $(1997,1998)$ used ribotyping or randomly amplified polymorphic (RAPD) DNA methods to compare strains of $F$. psychrophilum isolated from different countries and fish species and reported associations between ribotypes and hosts and between RAPD profiles and hosts (particularly isolates of trout origin). We caution that host-associations may be evident in a given data set, but because these analyses are based on clinical isolates rather than on a random sample from the population of all $F$. psychrophilum strains, the conclusions are tentative at best (Borucki et al. 2003). The same is true for the putative genetic lineages identified by Soule et al. (2005), which is why it is important to correlate the pattern using independent markers such as the 16S rRNA gene polymorphisms and phenotypic tests described herein. The hypothesis that strains are host-specific or host-associated will remain tentative until more molecular epidemiology studies have been conducted. Ideally, these studies will be backed by experimental infection models, although it has been difficult to develop a reliable model that mimics a natural infection (i.e. waterborne) for F. psychrophilum (Garcia et al. 2000, Madetoja et al. 2000).

The presence of multiple and distinct 16S rRNA sequences within single genomes is reportedly common for strains of the genus Vibrio (Moreno et al. 2002). This latter study also shows that the majority of polymorphisms are concentrated in the variable stemloop region of bacterial 16S rDNA. One of these regions, Variable Region 3 (Baker et al. 2003), is the area targeted by our fish pathogen microarray (Warsen et al. 2004). The high degree of variation in these variable regions is one reason they are attractive for identifying species-specific markers for pathogen detection. Nevertheless, it is clear that unexpected genetic variation in organisms like Vibrio (Moreno et al. 2002), Flavobacterium columnare (Wakabayashi \& Wakabayashi 1999), and F. psychrophilum (this study) can interfere with pathogen detection schemes that are based on 16S rRNA gene polymorphisms. False negatives are increasingly likely under these circumstances, and false positives might also be encountered.

One question that arises is why we had a clear sequencing chromatogram for the 16S rRNA gene of ATCC 49418 strain when there are at least 2 distinct template sequences present in this genome. We can only surmise that PCR amplification bias (Polz \& Cavanaugh 1998) in favor of more plentiful template (the ATCC 49418 sequence) overwhelms the signal from the CSF 259-95 sequence. Our speculation assumes that multiple copies of the 16S rRNA gene are present in these genomes and that there are more copies of the ATCC 49418 sequence in the ATCC 49418 strain.

We also detected phenotypic differences between strains. Interestingly, CSF 259-93 does not hydrolyze gelatin Type A, indicating that this phenotype is not necessary to cause pathology in an intramuscular 
injection challenge model for trout (LaFrentz et al. 2002). Differences in elastin hydrolysis have been described before (Bertolini et al. 1994, Madetoja et al. 2002), but in the present study our ability to classify the strains a priori as either Lineage I or II permitted us to verify statistically that elastin hydrolysis is highly correlated with these putative lineages.

Data from the current study indicate that isolates from Lineage II (mostly from trout) are more likely to have reduced susceptibility to tetracycline. Additional information is needed to better characterize the mechanisms of tetracycline resistance because recent reports show an increasing likelihood of encountering resistant strains of Flavobacterium psychrophilum (Rangdale et al. 1997, Bruun et al. 2000, Schmidt et al. 2000) and the level of resistance observed in the field appears to be clinically relevant (Bruun et al. 2003). Because tetracycline resistance can be conferred by polymorphisms in the 16S rRNA gene, it is useful to speculate that one of the 16S rRNA polymorphisms described in the present study confers resistance to tetracycline. Nevertheless, the 16S rRNA polymorphism in Lineage II isolates is also found in most Lineage I isolates, which is not consistent with this sequence polymorphism mediating resistance to tetracyclines. Furthermore, in cases where 16S rRNA polymorphisms have conferred resistance to tetracycline, the polymorphisms of interest do not correspond to the variable region 3 of the 16s rRNA gene (Hu \& Ochi 2001, Wu et al. 2005). Another possible explanation for increased resistance would be horizontally transmitted tetracycline resistance genes. The suppression subtractive hybridization experiments by Soule et al. (2005) detected evidence of a tet(A)-like gene sequence consistent with a reduced susceptibility to tetracycline for CSF 295-93 and other Lineage II isolates. When we compare the zone of inhibition from the Kirby-Bauer disc diffusion tests in the present study with the hybridization signal from the tet(A)-like probe described by Soule et al. (2005), there is a statistically significant association between presence of this putative gene (measured as a function of microarray hybridization signal) and reduced zone size $(p<0.001)$. Thus, it appears that most of the tetracycline resistance will be explained by a novel tetracycline resistance gene. Given the close association with reduced tetracycline susceptibility and elastase activity for Lineage II isolates, it is possible that the genes conferring these 2 traits are linked on a common mobilizable element.

A combination of suppression subtractive hybridization, DNA microarray hybridizations, 16S rRNA gene polymorphisms, elastin hydrolysis, and tetracycline resistance support the hypothesis that there are at least 2 distinct lineages of Flavobacterium psychrophilum. More isolates need to be characterized for these and other traits to further substantiate this hypothesis and to determine if additional lineages exist. One immediate implication from these findings is that polyvalent vaccines may be needed to effectively control this organism in aquaculture settings. The PCR-RFLP test described here could be used to assist subtyping of F. psychrophilum strains, although it should also be possible to develop a simple PCR test based on the polymorphisms described in Fig. 1.

Acknowledgements. We received generous isolate donations from J. Winton, P. W. Taylor, I. Dalsgaard, J. Bertolini, California Dept. Fish and Game, Utah Div. Wildlife Resources and the Washington Animal Disease Diagnostic Laboratory, and invaluable technical assistance and isolate collection and organization from B. LaFrentz and D. Stanek. This study was funded by the Washington and Idaho Aquaculture Initiative and the Agricultural Animal Health Program at the College of Veterinary Medicine, Pullman, WA, USA.

\section{LITERATURE CITED}

Baker GC, Smith JJ, Cowan DA (2003) Review and re-analysis of domain-specific $16 \mathrm{~S}$ primers. J Microbiol Methods 55:541-555

Baliarda A, Faure D, Urdaci MC (2002) Development and application of a nested PCR to monitor brood stock salmonid ovarian fluid and spleen for detection of the fish pathogen Flavobacterium psychrophilum. J Appl Microbiol 92: 510-516

Bauer AW, Kirby WMM, Sherris JC, Turch M (1966) Antibiotic susceptibility testing by a standardized single disk method. Am J Clin Pathol 45:493-496

Bernardet JF, Baudin-Laurencin F, Tixerant G (1988) First identification of Cytophaga psychrophila in France. Bull Eur Assoc Fish Pathol 8:104-105

Bertolini JM, Wakabayashi H, Watral VG, Whipple MJ, Rohovec JS (1994) Electrophoretic detection of proteases from selected strains of Flexibacter psychrophilus and assessment of their variability. J Aquat Anim Health 6:224-233

Borucki M, Peppin J, White D, Loge F, Call DR (2003) Variation in biofilm formation among strains of Listeria monocytogenes. Appl Environ Microbiol 69:7336-7342

Bruun MS, Schmidt AS, Madsen L, Dalsgaard I (2000) Antimicrobial resistance patterns in Danish isolates of Flavobacterium psychrophilum. Aquaculture 187:201-212

Bruun MS, Madsen L, Dalsgaard I (2003) Efficiency of oxytetracycline treatment in rainbow trout experimentally infected with Flavobacterium psychrophilum strains having different in vitro antibiotic susceptibilities. Aquaculture 215:11-20

Bustos PA, Calbuyahue J, Montaña J, Opazo B, Entrala P, Solervicens R (1995) First isolation of Flexibacter psychrophilus, as causative agent of rainbow trout fry syndrome (RTFS), producing rainbow trout mortality in Chile. Bull Eur Assoc Fish Pathol 15:162-164

Chakroun C, Urdaci MC, Faure D, Grimont F, Bernardet JF (1997) Random amplified polymorphic DNA analysis provides rapid differentiation among isolates of the fish pathogen Flavobacterium psychrophilum and among Flavobacterium species. Dis Aquat Org 31:187-196

Chakroun C, Grimont F, Urdaci MC, Bernardet JF (1998) 
Fingerprinting of Flavobacterium psychrophilum isolates by ribotyping and plasmid profiling. Dis Aquat Org 33:167-177

Crump EM, Perry MB, Clouthier SC, Kay WW (2001) Antigenic characterization of the fish pathogen Flavobacterium psychrophilum. Appl Environ Microbiol 67:750-759

Dalsgaard I, Madsen L (2000) Bacterial pathogens in rainbow trout, Oncorhynchus mykiss (Walbaum), reared at Danish freshwater farms. J Fish Dis 23:199-209

Ekman E, Borjeson H, Johansson N (1999) Flavobacterium psychrophilum in Baltic salmon Salmo salar brood fish and their offspring. Dis Aquat Org 37:159-163

Evensen Ø, Lorenzen E (1996) An immunochemical study of Flexibacter psychrophilus infection in experimentally and naturally infected rainbow trout (Oncorhynchus mykiss) fry. Dis Aquat Org 25:53-61

Garcia C, Pozet F, Michel C (2000) Standardization of experimental infection with Flavobacterium psychrophilum, the agent of rainbow trout Oncorhynchus mykiss fry syndrome. Dis Aquat Org 42:191-197

Groff JM, LaPatra SE (2000) Infectious diseases impacting the commercial culture of salmonids. J Appl Aquaculture 10: $17-90$

Hawke JP, Thune RL (1992) Systemic isolation and antimicrobial susceptibility of Cytophaga columnaris from commercially reared channel catfish. J Aquat Anim Health 4: 109-113

Holt RA (1987) Cytophaga psychrophila, the causative agent of bacterial cold-water disease in salmonid fish. $\mathrm{PhD}$ thesis, Oregon State University, Corvallis, OR

Holt RA, Amandi A, Rohovec JS, Fryer JL (1989) Relation of water temperature to bacterial cold-water disease in Coho Salmon, Chinook Salmon, and Rainbow Trout. J Aquat Anim Health 1:94-101

Hu H, Ochi K (2001) Novel approach for improving the productivity of antibiotic-producing strains by inducing combined resistant mutations. Appl Environ Microbiol 67: 1885-1892

Iguchi K, Ogawa K, Nagae M, Ito F (2003) The influence of rearing density on stress response and disease susceptibility of ayu (Plecoglossus altivelis). Aquaculture 220:515-523

Izumi S, Aranishi F, Wakabayashi H (2003) Genotyping of Flavobacterium psychrophilum using PCR-RFLP analysis. Dis Aquat Org 56:207-214

LaFrentz BR, LaPatra SE, Jones GR, Congleton JL, Sun B, Cain KD (2002) Characterization of serum and mucosal antibody responses and relative per cent survival in rainbow trout, Oncorhynchus mykiss (Walbaum), following immunization and challenge with Flavobacterium psychrophilum. J Fish Dis 25:703-713

LaFrentz BR, LaPatra SE, Jones GR, Cain KD (2003) Passive immunization of rainbow trout, Oncorhynchus mykiss (Walbaum), against Flavobacterium psychrophilum, the causative agent of bacterial coldwater disease and rainbow trout fry syndrome. J Fish Dis 26:371-384

LaFrentz BR, LaPatra SE, Jones GR, Cain KD (2004) Protective immunity in rainbow trout Oncorhynchus mykiss following immunization with distinct molecular mass fractions isolated from Flavobacterium psychrophilum. Dis Aquat Org 59:17-26

Lorenzen E, Dalsgaard I, Bernardet JF (1997) Characterization of isolates of Flavobacterium psychrophilum associated with coldwater disease or rainbow trout fry syndrome I: phenotypic and genomic studies. Dis Aquat Org 31:197-208

Madetoja J, Nyman P, Wilkund T (2000) Flavobacterium psychrophilum, invasion into and shedding by rainbow trout Oncorhynchus mykiss. Dis Aquat Org 43:27-38

Madetoja J, Hanninen ML, Hirvela-Koski V, Dalsgaard I,
Wiklund T (2001) Phenotypic and genotypic characterization of Flavobacterium psychrophilum from Finnish fish farms. J Fish Dis 24:469-479

Madetoja J, Dalsgaard I, Wiklund T (2002) Occurrence of Flavobacterium psychrophilum in fish-farming environments. Dis Aquat Org 52:109-118

Madsen L, Dalsgaard I (1999) Reproducible methods for experimental infection with Flavobacterium psychrophilum in rainbow trout Oncorhynchus mykiss. Dis Aquat Org 36:169-176

Madsen L, Dalsgaard I (2000) Comparative studies of Danish Flavobacterium psychrophilum isolates: ribotypes, plasmid profiles, serotypes and virulence. J Fish Dis 23: 211-218

Moreno C, Romero J, Espejo RT (2002) Polymorphism in repeated 16s rRNA genes is a common property of type strains and environmental isolates of the genus Vibrio. Microbiology 148:1233-1239

Muyzer G, de Waal EC, Uitterlinden AG (1993) Profiling of complex microbial populations by denaturing gradient gel electrophoresis analysis of polymerase chain reactionamplified genes coding for 16S rRNA. Appl Environ Microbiol 59:695-700

Nematollahi A, Decostere A, Pasmans F, Haesebrouck F (2003) Flavobacterium psychrophilum infections in salmonid fish. J Fish Dis 26:563-574

Obach A, Laurencin F (1991) Vaccination of rainbow trout Oncorhynchus mykiss against the visceral form of coldwater disease. Dis Aquat Org 12:13-15

Polz MF, Cavanaugh CM (1998) Bias in template-to-product ratios in multitemplate PCR. Appl Environ Microbiol 64: $3724-3730$

Rangdale RE, Richards RH, Alderman DJ (1997) Minimum inhibitory concentrations of selected antimicrobial compounds against Flavobacterium psychrophilum the causal agent of rainbow trout fry syndrome (RTFS). Aquaculture 158:193-201

Schmidt AS, Bruun MS, Dalsgaard I, Pedersen K, Larsen JL (2000) Occurrence of antimicrobial resistance in fishpathogenic and environmental bacteria associated with 4 Danish rainbow trout farms. Appl Environ Microbiol 66: 4908-4915

Soule M, Cain K, LaFrentz S, Call DR (2005) Combining suppression subtractive hybridization and microarrays to map the intraspecies phylogeny of Flavobacterium psychrophilum. Infect Immun 73:3799-3802

Toranzo AE, Barja JL (1993) Fry mortality syndrome (FMS) in Spain. Isolations of the causative bacterium Flexibacter psychrophilus. Bull Eur Assoc Fish Pathol 13:30-32

Wakabayashi H, Horiuchi M, Bunya T, Hoshiai G (1991) Outbreaks of cold-water disease in coho salmon in Japan. Fish Pathol 26:211-212

Wakabayashi T, Wakabayashi H (1999) Genotypic diversity of strains of Flavobacterium columnare from diseased fishes. Fish Pathol 34:65-71

Warsen AE, Krug MJ, LaFrentz S, Stanek DR, Loge FJ, Call DR (2004) Simultaneous discrimination between 15 fish pathogens by using 16S ribosomal DNA PCR and DNA microarrays. Appl Environ Microbiol 70:4216-4221

Wiklund T, Kaas K, Lonnstrom L, Dalsgaard I (1994) Isolation of Cytophaga psychrophila (Flexibacter psychrophilus) from wild and farmed rainbow trout (Oncorhynchus mykiss) in Finland. Bull Eur Assoc Fish Pathol 14:44-46

Wu JY, Kim JJ, Reddy R, Wang WM, Graham DY, Kwon DH (2005) Tetracycline-resistant clinical Helicobacter pylori isolates with and without mutations in 16S rRNA-encoding genes. Antimicrob Agents Chemother 49:578-583 